\title{
Notch-Inflammation Networks in Regulation of Breast Cancer Progression
}

\author{
Yulia Liubomirski and Adit Ben-Baruch *
}

School of Molecular Cell Biology and Biotechnology, George S. Wise Faculty of Life Sciences, Tel Aviv University, 6997801 Tel Aviv, Israel; yulialiu@post.tau.ac.il

* Correspondence: aditbb@tauex.tau.ac.il; Tel.: +972-3-640-7933

Received: 20 May 2020; Accepted: 24 June 2020; Published: 28 June 2020

\begin{abstract}
Members of the Notch family and chronic inflammation were each separately demonstrated to have prominent malignancy-supporting roles in breast cancer. Recent investigations indicate that bi-directional interactions that exist between these two pathways promote the malignancy phenotype of breast tumor cells and of their tumor microenvironment. In this review article, we demonstrate the importance of Notch-inflammation interplays in malignancy by describing three key networks that act in breast cancer and their impacts on functions that contribute to disease progression: (1) Cross-talks of the Notch pathway with myeloid cells that are important players in cancer-related inflammation, focusing mainly on macrophages; (2) Cross-talks of the Notch pathway with pro-inflammatory factors, exemplified mainly by Notch interactions with interleukin 6 and its downstream pathways (STAT3);

(3) Cross-talks of the Notch pathway with typical inflammatory transcription factors, primarily NF-kB. These three networks enhance tumor-promoting functions in different breast tumor subtypes and act in reciprocal manners, whereby Notch family members activate inflammatory elements and vice versa. These characteristics illustrate the fundamental roles played by Notch-inflammation interactions in elevating breast cancer progression and propose that joint targeting of both pathways together may provide more effective and less toxic treatment approaches in this disease.
\end{abstract}

Keywords: breast cancer; inflammatory cells; interleukin 6; macrophages; NF- $\mathrm{kB}$; Notch ligands; Notch receptors; pro-inflammatory cytokines

\section{Introduction}

The Notch pathway controls many developmental processes, where it dictates cell fate determination, differentiation and tissue homeostasis (representative review articles: [1-6]). Members of the Notch pathway-namely the transmembrane receptors Notch 1-4 and the transmembrane ligands Delta-like (DLL) 1, 3, 4 and Jagged (Jag) 1, 2 in mammals-also regulate pathological conditions; by mediating cell-to-cell contacts between the cancer cells themselves, and between tumor cells and adjacent cells, they control tumor growth and metastasis. Extensive research has demonstrated that the interactions between Notch receptors and ligands regulate gene transcription and intracellular events in cancer cells and in cells of the tumor microenvironment (TME), by that greatly contributing to the complex net of interactions that shapes the consequences of the malignancy process [7-11].

Breast cancer (BC) is one of the cancer types in which Notch signaling leads to multiple pro-metastatic events that can take place in the tumor cells themselves as well as at the TME, as has been summarized by recent reviews (e.g., [11-18]). Members of the Notch family have been extensively studied in $\mathrm{BC}$, where the disease is now molecularly categorized to four main subtypes based on the expression of estrogen receptors (ERs), progesterone receptors (PRs) and human epidermal growth factor receptor 2 (HER2). The highly aggressive triple negative (TNBC) subtype is so named because it lacks the presence of these three receptors, and accordingly it cannot be treated by receptor-targeting 
therapies; rather, the conventional treatment in TNBC is chemotherapy. Alongside with TNBC (corresponding to the term "basal-like" in genomic analyses), the other three BC subtypes consist of luminal-A tumors that account for over $40 \%$ of the patients, express ERs/PRs only and have a relatively good prognosis; luminal-B tumors that express ERs/PRs but can also carry HER2 amplification or relatively high ki67 levels; and HER2+ tumors that lack ERs and PRs [18-20].

Increasing evidence indicates that Notch signaling is strongly involved in $\mathrm{BC}$, generally promoting malignancy cascades [11-18]. The initial evidence for the pro-tumor roles of Notch family members in BC progression arose from mouse mammary tumor virus (MMTV) studies, where the insertion site for MMTV was Notch4, converting mammary epithelial cells to neoplastic cells in mice [21,22]. With time, it was demonstrated that many Notch family members promote pathogenesis in $\mathrm{BC}$ at many different stages of disease. This is illustrated for example by studies on tumor initiation (Notch1; Notch3), stem cell control (Notch1; Notch4; Jag1; Jag2; DLL1), angiogenesis (Notch1; DLL4) invasion and metastasis in remote organs (Notch1; Notch2; Jag1; DLL1) [23-39].

Particularly, Notch1 has emerged as an important regulator of BC progression. Alongside with findings demonstrating that Notch1 (and Jag1) expression were significantly associated with poor overall survival in BC in general [32], many studies connected Notch1 to TNBC in particular. Notch1 was found to be hyper-activated or over-expressed in TNBC, and its elevated levels were linked to poor overall survival and chemotherapy resistance [29-33]. Often, constitutive activation of Notch1 in TNBC resulted from gene rearrangements, deletions and mutations in the PEST domain [40-42]. However, in view of the fact that Notch1 activating mutations were observed in only a subset of TNBC patients [40-42] the identity of other regulatory mechanisms that affect Notch activities in TNBC and in $\mathrm{BC}$ in general, have been the subject of growing interest.

Between others, the search for defined mechanisms that control Notch activities in cancer has addressed Notch-TME interactions. Specifically, inflammatory processes were addressed in view of their fundamental roles in promoting tumor cell proliferation and invasion, immune suppression and angiogenesis [43-47]. Along these lines, the different studies investigated the connections between the Notch pathway and inflammatory elements: cells, soluble mediators and transcription factors. This is also so in $\mathrm{BC}$, where inflammatory processes are tightly connected to more aggressive disease and chemoresistance [48-62].

In this review article, we exemplify the importance of Notch-inflammation networks in regulating cancer progression by focusing on BC, where both Notch and inflammation are central determinants. To illustrate the current knowledge and emphasize key processes, this manuscript focuses on three exemplary networks, in which Notch family members promote BC aggressiveness through interactions with pro-inflammatory elements: (1) Cross-talks of the Notch pathway with myeloid cells that contribute to cancer-related inflammation, specifically with macrophages; (2) Cross-talks of the Notch pathway with pro-inflammatory soluble mediators, particularly interleukin 6 (IL-6) and IL-6-driven pathways (through the transcription factor signal transducer and activator of transcription 3, STAT3); (3) Cross-talks of the Notch pathway with transcription factors that promote inflammatory processes, mainly nuclear factor-kappaB (NF- $k B$ ). Following these three sections, we conclude this article by discussing the implications of Notch-inflammation interplays in cancer research and therapy, in BC and in general.

\section{Network No. 1: Cross-Talks of the Notch Pathway with Myeloid Cells that Contribute to Cancer-Related Inflammation}

The TME in BC is characterized by the presence of myeloid cells that generally enhance tumor progression. Myeloid-derived suppressor cells (MDSCs) and N2 neutrophils are known to elevate malignancy cascades [63-66], yet with relatively limited understanding of their cross-talks with Notch family members in BC (e.g., [67]). In parallel, the macrophage sub-population is not only highly present in breast tumors but also integrates many pro-tumor activities via interactions with the Notch pathway (as described further below). 
Macrophages are major contributors to cancer-related inflammation and regulate many stages of tumor progression [68-70]. To follow up on the conventional categorization of M1 "classically activated" and M2 "alternatively activated" macrophages, very often tumor-associated macrophages (TAMs) are considered as M2-polarized cells that promote tumor cell proliferation, angiogenesis, immune suppression and other key tumor-supporting events [70-72]. In parallel, M1 macrophages are generally regarded as anti-tumor cells that constitute a major source for pro-inflammatory cytokines such as tumor necrosis factor $\alpha$ (TNF $\alpha$ ) and interleukin-1 $\beta$ (IL-1 $\beta$ ) [70,73]; whereas these cytokines can promote anti-tumor activities at certain stages of the malignancy process, they are also often linked to chronic inflammation and to pro-metastatic effects in BC and other malignancies as well [45,74-79]. In this context, it is important to note that actually, macrophage types are not dichotomic but rather these cells demonstrate a very high level of plasticity that leads to a continuum of phenotypes and activities [80,81].

In view of their prominent roles in breast malignancy and ability to regulate cancer progression through interactions with the Notch pathway [82], Notch-macrophage cross-talks in BC exemplify well the way such networks may act to promote disease course. In this respect, it is interesting to note that a recent publication demonstrated that macrophage infiltration was denser and Jag1 expression levels were higher in BC patients who developed resistance to treatment with aromatase inhibitors (AI) than in AI-sensitive patients. In the total cohort, both parameters were significantly associated with clinico-pathological parameters and poor survival [83]. Similarly, analyses of biopsies of patients diagnosed with invasive micropapillarly carcinoma of the breast (IMPC) demonstrated significant correlation of Jag1 expression with macrophage infiltration, and both parameters were negatively linked to disease-free survival in this relatively aggressive type of disease [84].

This association of Jag1 expression with macrophages suggests that members of the Notch family may be functionally connected to pro-tumor macrophage activities in BC. Indeed, several studies indicated that the expression of Notch receptors by macrophages played important roles in regulating the pro-malignancy functions of $\mathrm{BC}$ cells (Figure 1(A1)). In other cases, $\mathrm{BC}$ cells were those that expressed Notch receptors (Figure 1(A2)), and eventually vicious cycles of interactions between macrophages and BC cells through Notch receptors and their ligands were reported, as described below.

An example for tumor interactions with Notch-expressing macrophages was identified when lactate-treated macrophages demonstrated elevated release of the chemokine CCL5, induced through Notch1 signaling; then, the chemokine induced the activation of its corresponding receptor CCR5 in the cancer cells. This interaction has led to increased aerobic glycolysis in the tumor cells, which also acquired elevated epithelial-to-mesenchymal properties and migratory activities [85] (Figure 1(A1)). Additional evidence for Notch-regulated networks was revealed in $\mathrm{BC}$ when in long-term endocrine depleted luminal-A BC cells (LTED) the expression of Jag1 was elevated, and macrophages that grew in culture with such LTED cells acquired an M2 phenotype, in a Notch-dependent manner. The resulting M2 macrophages released factors that elevated the migration of the tumor cells, thus revealing an interactive loop between the cancer cells and macrophages via members of the Notch pathway [83] (Figure 1(A1)).

In parallel, it was found that the terminal differentiation of macrophages to TAMs-that did not demonstrate the alternatively activated phenotype of M2 macrophages-depended on recombination signal-binding protein for immunoglobulin kappa J region (RBPJ) [86], known to act together with Notch intracellular domain (NICD) in gene expression regulation [87]; in turn, these RBPJ-expressing TAMs were found to down-regulate the levels of granzyme-expressing CD8+ T cells and to elevate tumor burden in a BC model [86]. 

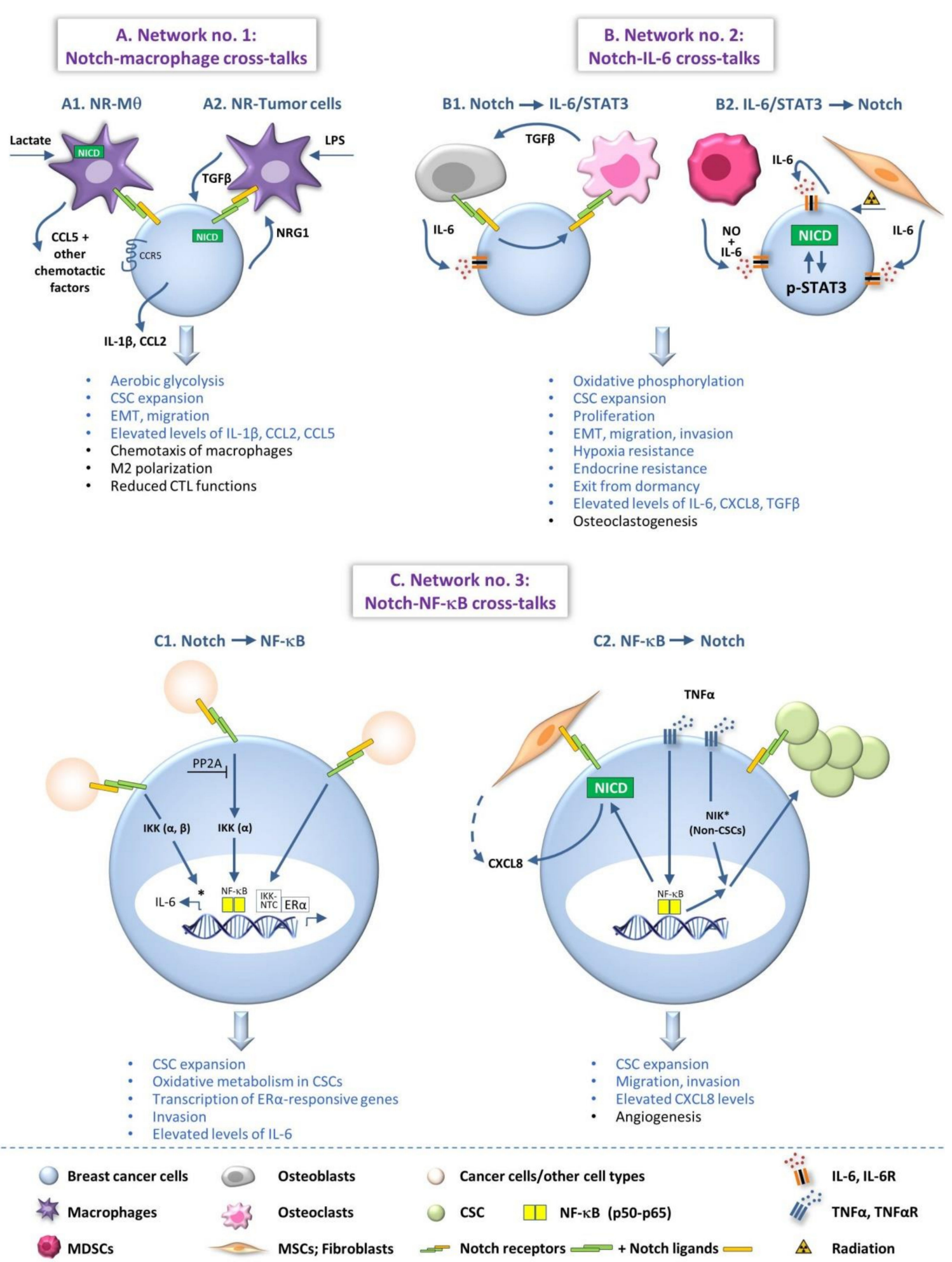

Figure 1. Notch-inflammation networks that promote breast cancer progression. The Figure demonstrates three major networks that are established between members of the Notch pathway and inflammatory elements in BC. For the sake of simplicity, not all processes and not all mechanistic details that were described in the different studies are demonstrated in the Figure. When several processes that were identified in different publications are illustrated in the same cell/setting, there is no intention to imply that they take place simultaneously. In the text, the readers are referred to the relevant parts that are demonstrated in the Figure. Three Notch-inflammation networks are demonstrated in the Figure: (A) Network no. 1-Cross-talks between the Notch pathway and macrophages, as key representatives 
of myeloid cells that contribute to cancer-related inflammation; (A1) Effects of tumor-induced activation of Notch signaling in macrophages; (A2) Effects of macrophage-induced activation of Notch signaling in the tumor cells. (B) Network no. 2-Cross-talks between the Notch pathway and IL-6-a major pro-inflammatory cytokine that is one of many pro-inflammatory factors prevailing in breast tumors and promoting disease progression-and its downstream pathways (STAT3); (B1) Effects of Notch activation on IL-6/STAT3 signaling; (B2) Effects of IL-6/STAT3 signaling on Notch activation in the tumor cells. (C) Network no. 3-Cross-talks between the Notch pathway and the NF- $\mathrm{kB}$ transcription factors, which have prominent roles in inflammatory processes and mediate pro-inflammatory/pro-metastatic effects in many malignancies, including BC; (C1) Effects of Notch signaling through activation of the NF- $\mathrm{B}$ pathway, on breast tumor cells; (C2) Effects of NF-kB-mediated effects through Notch activation on breast cancer cells. ${ }^{*}$, aspects concerning the activation of non-classical NF- $\kappa B$ pathways. In the texts describing the pro-tumor consequences of the Notch-inflammation networks, the blue text signifies pro-malignancy effects potentiated in the tumor cells and the black text illustrates tumor-promoting activities at the TME. Please note that factors released by the cancer cells can also affect the characteristics of the TME. CSCs, cancer stem cells; CTLs, cytotoxic T cells; EMT, epithelial-to-mesenchymal transition; ER $\alpha$, estrogen receptor $\alpha$; IKK, IKB kinase; IL-6, interleukin 6; IL-6R, IL-6 receptor; LPS, lipopolysaccharide; MDSCs, myeloid-derived suppressor cells; MSCs, mesenchymal stem cells; M $\theta$, macrophages; NICD, Notch intracellular domain; NIK, NF-kB inducing kinase; NO, nitric oxide; NR, Notch receptors; NRG1, Neuregulin 1; NTC, Notch-CSL-MAML1 transcriptional complexes; TGF $\beta$, transforming growth factor $\beta ; \mathrm{TNF} \alpha$, tumor necrosis factor $\alpha ; \mathrm{TNF} \alpha \mathrm{R}, \mathrm{TNF} \alpha$ receptor.

As indicated above, other studies demonstrated that the reciprocal mode of activation can also exist, in which the tumor cells are those expressing Notch receptors. For example, in a study of basal-like BC cells it was found that lipopolysaccharide (LPS) treatment of macrophages induced the expression of Jag1 in these cells; based on other findings provided in that study, the authors suggested that through such Jag1 up-regulation the macrophages could have led to Notch activation in cancer stem cells (CSCs) and then to their expansion [88] (Figure 1(A2)). In another study, it was found that TNBC cells expressed neuregulin 1 (NRG1) that activated macrophage-expressed ErbB3, leading to increased expression of Jag1 by the macrophages; then, when the two cells interacted in co-culture, Jag1 was necessary for induction of tumor cell trans-endothelial migration (presumably by binding to cancer cell-expressed Notch) [89].

Another illustration to a situation in which Notch receptor-expressing BC cells and macrophages cross-talk with one another, was found in a recent study demonstrating that TAM-derived transforming growth factor $\beta 1$ (TGF $\beta 1$ ) has activated the Notch1 pathway in basal-like BC cells, giving rise to increased production of IL-1 $\beta$ and of the monocyte chemoattractant CCL2 in the presence of macrophages [90]; as a result, the recruitment of macrophages to the tumor area was increased, and has further facilitated the TGF $\beta$-mediated activation of the tumor cells by macrophages through Notch (Figure 1(A2)). In this case, both Notch3 and Jag1 were involved in the process and their inhibition gave rise to smaller tumors, accompanied by reduced IL-1 $\beta$ and CCL2 levels in the tumors and lower macrophage presence [90].

Overall, the above findings illustrate the interactions between BC cells and macrophages that are mediated by Notch-related pathways, and demonstrate how such processes can generate vicious cycles that strongly promote disease course. In addition, the Notch pathway can dictate the phenotype of leukocytes that infiltrate the tumor site, for example by regulating the expression of chemokines that promote the presence of TAMs at the tumor setting, by that strongly affecting the malignancy cascade in BC.

\section{Network No. 2: Cross-Talks of the Notch Pathway with Pro-Inflammatory Soluble Mediators}

The TME is enriched not only with inflammatory cells but also with a large number of pro-inflammatory soluble mediators. Many of these factors were linked to a less favorable disease course in cancer, and play causative roles in promoting tumor progression. Specifically, pro-inflammatory 
cytokines and inflammatory chemokines were reported to have a strong tumor-supporting impact on cancer development and metastasis, as illustrated by many studies of BC and other cancer types as well (e.g., $[45,74-79,91-96])$.

In parallel, different studies indicated that the pro-inflammatory mediators TNF $\alpha$ and IL-1 $\beta$, as well as the inflammatory chemokines CXCL8 (IL-8), CCL2 (MCP-1) and CCL5 (RANTES)-that are major contributors to BC progression $[45,74-79,93-96]$ - were connected to Notch activities in BC. For example, evidence from our studies indicated that co-culturing of TNBC cells with mesenchymal stromal cells (MSCs) or cancer-associated fibroblasts (CAFs) in the presence of TNF $\alpha$ or IL-1 $\beta$ stimulation has given rise to contact-dependent increase in CXCL8, CCL2 and CCL5 levels in the co-cultures. Under these conditions, it was Notch1 activation-mainly in the cancer cells but also to some degree in the MSCs-that has led to CXCL8 up-regulation (to be described in more detail below; see also Figure 1(C2)). Then, CXCL8 has significantly contributed to elevated tumor cell migration and invasion, and also to increased angiogenesis $[97,98]$. Eventually, TNBC cells that formed physical contacts with MSCs in the presence of TNF $\alpha$ stimulation gave rise to increased incidence of lung metastasis [97]. Other research works in the field also indicated that these same inflammatory factors stand in the basis of Notch interplays that contribute to BC progression [85,88,90,99-102].

With these findings in mind, it is interesting to note that another pro-inflammatory cytokine, IL-6 has been highly implicated in tumor-promoting processes $[79,91,92]$ and in Notch-related pathways in BC. Here, two main lines of evidence were obtained: the first is that Notch pathway activities have given rise to tumor-promoting functions in BC via IL-6 and STAT3 activation (Figure 1(B1)), and the second is that IL-6 stimulation/STAT3 activation has led through Notch family members to pro-metastatic activities in BC (Figure 1(B2)).

In the first line of research, the ability of Notch family members to activate IL-6/STAT3-mediated pathways was reported in a study that addressed resistance of luminal-A BC cells to tamoxifen. In this research, it was found that Notch4 activated STAT3 and that this pathway has induced epithelial-to-mesenchymal transition (EMT) in tamoxifen-resistant tumor cells [103]. In this context, it is interesting to note that complex interactions between the Notch and IL-6 pathways were reported in another study. In this case, inhibition of Notch3 has given rise to elevated tumor growth and to increased IL-6 expression by the tumor cells, which then caused CSC expansion. This effect of Notch3 inhibition was abrogated by IL-6R antagonist in animal studies and reduced the generation of CSCs. When general inhibition of the Notch pathway was introduced in animal studies by $\gamma$-secretase inhibitors (GSI), the addition of IL-6R antagonist has potentiated the ability of GSI to reduce the frequency of CSCs in tumors [104].

In another study that exemplifies the roles of Notch pathway in inducing IL-6/STAT3 activation in BC tumorigenesis, it was found that Jag1-IL-6 interactions acted on the TME and have led to increased bone metastasis in a TNBC model (Figure 1(B1)). This study demonstrated that Jag1 expression by the tumor cells mediated their interactions with osteoblasts, promoting their ability to release IL- 6 that elevated tumor cell proliferation. In addition, it was found that activated Jag1 mediated interactions of the tumor cells with osteoclasts [105]. In turn, osteoclasts have induced bone osteolysis and facilitated bone metastasis, accompanied by increased release of TGF $\beta$; TGF $\beta$-SMAD signaling has then further supported Jag1/IL-6-mediated interactions between the osteoblasts and the cancer cells, leading to a positive feedback loop that further promoted the metastatic process in bones [105] (Figure 1(B1)).

In parallel, the reciprocal direction of IL-6/STAT3-mediated induction of Notch activation was also reported. In this context, it was demonstrated that MDSCs elevated tumor growth and stemness in BC, and also produced IL- 6 and nitric oxide (NO). In turn, IL-6 has induced STAT3 activation and NO has given rise to increased Notch activation in tumor cells (Figure 1(B2)). Of interest was the fact that Notch activities have led to persistent activation of STAT3 following IL-6 stimulation, and the cooperative activities of STAT3 and the Notch pathway resulted in increased generation of CSCs [67]. In a similar manner, autocrine IL-6-driven STAT3 activation has given rise to Notch3/Jag1 activation that sustained the enrichment of CSCs, and through Notch3 activation also has led to hypoxia resistance 
and increased invasion of BC cells [106] (Figure 1(B2)). In a parallel study, IL-6 was directly connected to BC stemness by inducing the activation of integrin-linked kinase (ILK), which has led to Notch1 activation and to assembly of functional $\gamma$-secretase complexes localization in caveolae, then giving rise to elevated CSC expansion [107].

Interestingly, in regards to Notch-inflammation regulation of stemness in BC, a recent study integrated mathematical modeling to reveal the underlying principles of experimentally-observed intra-tumor heterogeneity of different subsets of CSCs. This computational model predicted that due to spatial gradients of EMT-inducing signals such as TGF $\beta$ together with Notch-Jag1 activation, CSCs exhibit varying EMT phenotypes depending on their localization at the tumor mass, from the invasive edge to the core. Moreover, this study demonstrated that inflammatory cytokines such as IL-6, enable a subpopulation of cancer cells to display a hybrid epithelial/mesenchymal phenotype by enhancing Notch-Jag1 signaling and increasing the CSC population [108].

In addition to the IL-6-Notch interactions that promoted stemness, this axis was also found to up-regulate tumor cell motility in BC. Fractionated radiation of BC cells has led to increased production of IL-6 and CXCL8, and inhibition of each of these factors has given rise to reduced tumor cell migration and invasion (Figure 1(B2)); here, it was also found that IL-6 acted through JAK/STAT3 to activate Notch2-Jag1/DLL4 interactions that elevated EMT characteristics in BC cells [109] (Figure 1(B2)). In another research, it was demonstrated that IL-6 derived from senescent fibroblasts has led through STAT3 activation to Notch3 and Jag1 activation [110] (Figure 1(B2)). In addition, IL-6 activities in $\mathrm{BC}$ were found to be mediated through activation of the bromodomain and extraterminal (BET) protein BRD4 that was required for Notch1-mediated pro-tumor activities [25]. In these cases, the activation of these members of the Notch pathway increased tumor cell migration, invasion and proliferation $[25,110]$ (Figure 1(B2)).

Complementing these levels of IL-6/STAT3-driven pro-tumor activities in BC is the aspect of endocrine resistance. A recent study demonstrated that ER-expressing BC cells acquired endocrine resistance that was accompanied by elevated oxidative phosphorylation, in a process that depended on IL-6/STAT3-driven activation of Notch3. Eventually, this process stood in the basis of tumor cell self-renewal of CD133-high/CD44-low cells that has given rise to exit from dormancy and metastatic recurrence of ER-low BC cells that were resistant to endocrine therapy [111].

To conclude, the above investigations indicate that Notch-IL-6 interplays stand in the center of tumor progression in $\mathrm{BC}$, where the interactions could be reciprocal, depending on the cell system and on the parameters that were addressed. Here, Notch family members could lead to IL-6/STAT3 activation, and in other cases the IL-6/STAT3 pathway has given rise to Notch activation, eventually promoting a diversity of tumor-promoting processes in $\mathrm{BC}$ cells.

\section{Network No. 3: Cross-Talks of the Notch Pathway with Transcription Factors that Promote Inflammatory Processes}

Transcriptional regulation of cancer-related inflammatory processes is complex and orchestrated by many signaling pathways and transcription factors such as STAT3, AP-1 and NF- $\mathrm{kB}$. The findings summarized above on networks established between the Notch pathway and IL-6 portrayed the tight interplay that exists between Notch receptors/ligands with STAT3 in BC; several lines of evidence also addressed the interactions of Notch family members with JNK/AP-1 in BC [112,113].

In parallel, growing interest has been demonstrated in cross-talks that may be established between the Notch pathway and the NF-KB pathway. Here, the different studies revealed interactions of Notch with the classical (canonical) NF- $\kappa B$ pathway in which heterodimers of I $\mathrm{B}$ kinase $\alpha$ (IKK $\alpha$ ) and IKK $\beta$ lead to activation of p50 and p65 (RELA), typically induced by pro-inflammatory cytokines such as TNF $\alpha$ and IL-1 $\beta$ and infection-related signals. Other reports indicated that Notch also cross-talks with the non-classical (alternative, non-canonical) NF- $\mathrm{KB}$ pathway, where the players are mainly NF- $\mathrm{kB}$ inducing kinase (NIK), homodimers of IKK $\alpha$ and the activation of p52 and RELB; in this case, 
activation is induced by divergent stimulators, including members of the TNF family members, such as lymphotoxin [114,115].

To date, many reports have described a bi-directional regulation of Notch and NF- $\mathrm{kB}$ through different, context-dependent mechanisms and their diverse roles in physiological and in pathological conditions (representative reviews: [116-119]). Similarly, in cancer, efforts were devoted to deciphering Notch-NF- $\mathrm{KB}$ interactions and the way they affect the malignant behaviors of tumor cells and of the TME $[114,115,120,121]$. Cross-talks between the Notch pathway and the NF-kB-mediated route-primarily of the classical mode-are highly relevant for BC progression. In this malignancy, members of the Notch pathway play prominent roles in regulating disease course (as was described above) and in parallel elevated activation of NF- $\mathrm{KB}$ drives BC tumor development and progression at many different levels $[114,120,121]$.

Indeed, it was found that the Notch and NF- $\mathrm{KB}$ pathways promote $\mathrm{BC}$ progression by regulating each other's activities, at many levels. Here, again, reciprocal modes of activation were revealed: one mode in which members of the Notch pathway have activated the NF- $k B$ route (Figure $1(C 1)$ ) and a second mode in which NF- $\mathrm{kB}$ activation has given rise to stimulation of the Notch pathway (Figure 1(C2)).

One of the indications to possible Notch1-mediated increase in malignant features of BC cells through p65 activation was provided by a study demonstrating that Notch1 activation in TNBC cells increased the proliferation, adhesion, invasion and motility of the tumor cells. In parallel, Notch1 induced accumulation of $\mathrm{p} 65$ in the nucleus, elevated IкB $\alpha$ degradation and up-regulated the formation of NF- $\mathrm{BB}-\mathrm{DNA}$ complexes, suggesting that Notch1 induced tumor-promoting activities by activating NF- $\mathrm{B}$ [122]. In a follow-up study, direct evidence to such a scenario was revealed in motility-related aspects, when the authors have shown that Notch1-induced invasion of the cancer cells depended on NF- $\mathrm{KB}$ activation. Moreover, the study has shown that Notch1-induced NF- $\mathrm{KB}$ activation was governed by the PI3K/AKT pathway and IKK, and was negatively regulated by PP2A [123] (Figure 1(C1)). In another report, where Notch1 was found to induce pro-tumor activities in luminal-A BC cells and in the non-transformed breast epithelial cells in culture, Notch1 was also found to induce p65 activation [101].

Complementing these findings, another study revealed that the Notch pathway up-regulated NF- $\mathrm{KB}$ activation, mitochondrial metabolism and CSCs in TNBC cells. Here, it was found that activation of Notch1 by Jag1 promoted cellular bioenergetics via IKK $\alpha$-mediated activation of AKT in TNBC cells; In parallel, Notch1 activation in TNBC cells by Jag-expressing fibroblasts has promoted the recruitment of p50, p65 and IKK $\alpha$ to cIAP-2 promoter [124] (Figure 1(C1)). In addition, GSI treatment in combination with IKK or AKT inhibitors significantly abrogated the growth of mammospheres that were generated from TNBC cell lines and from flow-sorted CD44+/CD24-low or CD90-high CSCs. Eventually, it was found that mammospheres had increased oxidative metabolism that was sensitive to inhibition of the Notch, IKK and AKT pathways. Overall, these data indicate that Jag1-Notch1 acted through IKK $\alpha$ to trigger two parallel and potentially interacting pathways: mTORC2-dependent AKT activation that increased mitochondrial metabolism and a p50-p65-mediated pathway that triggered transcriptional activation [124] (Figure 1(C1)).

Key roles of IKK $\alpha$ in mediating Notch signaling were also revealed in luminal-A BC cells, where IKK $\alpha-$ Notch interactions promoted gene transcription by ER $\alpha$. This study provided evidence to a complex network of interactions, in which Jag1-induced Notch1 activation was followed by the recruitment of IKK $\alpha$ to Notch-CSL-Mastermind-like 1 (MAML1) transcriptional complexes (NTCs), accompanied by ER $\alpha$ binding and transcription of relevant genes; Notch1-induced p300 recruitment by MAML1 could also give rise to transcription of ER $\alpha$-responsive genes in the absence of estrogen [125] (Figure 1(C1)).

In addition to controlling the classical NF- $\mathrm{kB}$ pathway, it was found that Notch could elevate pro-inflammatory characteristics in BC through non-classical NF-kB mechanisms [126]. In this study, it was demonstrated that Notch-mediated induction of IL- 6 was inhibited by siRNA to IKK $\alpha$ or IKK $\beta$, 
but was independent of $\mathrm{p} 50$ of the classical NF- $\mathrm{kB}$ route; moreover, Notch activation did not affect the activation levels of p65 [126] (Figure 1(C1)). Therefore, this research has demonstrated that not only classical but also non-classical NF- $\mathrm{kB}$ mechanisms are activated by the Notch pathway in BC.

The above findings demonstrated that the Notch pathway plays important roles in un-regulating the activation of NF-KB-related mechanisms, which eventually have led to pro-tumor effects in BC. As mentioned above, evidence for the reciprocal axis was also provided, indicating that the NF- $\kappa B$ pathway controlled Notch-mediated signaling (Figure 1(C2)). Here, our recent publications aforementioned $[97,98]$ demonstrated that TNF $\alpha$ stimulation of direct co-cultures of TNBC cells with MSCs has given rise to elevated migration and invasion of the tumor cells and to increased release of angiogenic factors, in a process that was CXCL8-dependent. The TNF $\alpha$-induced increase of tumor cell motility and CXCL8 production by contact TNBC co-cultures with MSCs were inhibited by GSI, and direct involvement of Notch1 was demonstrated in up-regulating CXCL8 production [97,98]. In analyses of the molecular mechanisms we found that following TNF $\alpha$ stimulation of such co-cultures, p65 was activated in both cell types but more so in the cancer cells; moreover, p65 activation mainly in TNBC cells, but also in the MSCs, up-regulated the expression and activation of Notch1 in the tumor cells, which then promoted CXCL8 production primarily in the cancer cells [98] (Figure 1(C2)). Overall, our data demonstrated that p65-induced Notch1 activation was required for the contact-dependent induction of CXCL8 in the tumor-stroma-inflammation network, promoting malignancy-related function in TNBC cells.

In parallel, in a study mentioned above [88] it was found that NF-kB-induced up-regulation of Jag1 expression in non-CSCs has led to activation of the Notch pathway in CSCs and to expansion of this sub-population. In this investigation, NF- $\mathrm{KB}$ was activated by TNF $\alpha$ or in a non-classical manner by NIK, leading through Jag1 to activation of Notch signaling in the CSC sub-population (Figure 1(C2)). Moreover, BC clinical data and additional in vitro analyses suggested that the NF- $\mathrm{kB}-J a g 1$ axis was unique to the basal-like subtype and had specific role in the maintenance of the CSCs [88]. The findings of this study also suggested that Jag1-expressing macrophages, fibroblasts and other cells of the breast TME, may contribute to the self-renewal of CSCs in an NF-KB-Notch-dependent manner [88].

The findings described above provide evidence to complex interactive relationships of the Notch pathway with transcription factors that are typically involved in inflammatory processes, which may act in bi-directional and cooperative manners. Together with the previous sections, which exemplified other levels of Notch-inflammation cross-talks, the Notch-NF- $\mathrm{kB}$ network emphasizes the profound impact of combined Notch-inflammation regulatory networks on $\mathrm{BC}$ progression.

\section{Discussion}

Notch receptors and their ligands stand in the center of many developmental and pathological processes, in which they exert their impacts by mediating cell-to-cell contacts. This highly conserved pathway also strongly affects tumor progression by mediating the signal flow from external elements to transcription regulation. An increasing body of evidence indicates that the TME, with its pro-inflammatory elements, is strongly connected to Notch pathway regulation and activities. Furthermore, members of the Notch family are connected to transcription factors that are typically involved in regulation of inflammatory conditions.

In this review article, we chose to focus on BC in order to exemplify the interplay between Notch family members and inflammation. In this malignancy, both partners were shown to play key roles in promoting disease course, and recent studies indicate that multiple levels of interactions between them take place and promote tumor progression. In this context, we described the interplays of the Notch pathway with three inflammatory elements: (1) Myeloid inflammatory cells, mainly macrophages; (2) Pro-inflammatory soluble mediators, primarily IL-6 and its signaling pathway; and (3) Transcription factors that integrate pro-inflammatory signals, with major emphasis on NF- $\mathrm{kB}$. These three networks indicated that Notch1 and Jag1 were the key family members that participated in Notch-inflammation 
cross-talks, with observations pointing at other partners - such as Notch2, Notch3, Notch4 and DLL4 as important potential regulators in these settings, as well.

The research works summarized above have indicated that Notch-inflammation interplays strongly promote the malignancy phenotype, in vitro and/or in vivo, by advancing pro-tumor processes that take place primarily in the malignant cells but also at the TME. Specifically in the cancer cells, many different levels were positively affected by the Notch-inflammation networks, such as: increase in metabolic processes; CSC expansion; elevated tumor cell proliferation; increased EMT, migration and invasion; higher resistance to hypoxia and endocrine treatments, and transcription of ER $\alpha$-responsive genes; and elevated release of pro-inflammatory /metastasis-promoting factors such as IL-1 $\beta$, IL-6, CCL2, CXCL8 and TGF $\beta$. Obviously, the release of such soluble mediators can mediate the impacts of cancer cells on their TME. In parallel, Notch-inflammatory interactions could lead at the TME to increased levels of TAMs that have tumor-promoting activities; they could also dictate the phenotype of the macrophages at the tumor site, induce immune-suppression, mediate tumor-stroma interactions that promote malignancy, enhance angiogenesis and elevate metastasis by increasing bone osteolysis.

The above findings revealed shared characteristics between the three Notch-inflammation networks. First, the tumor-promoting activities of Notch-inflammation interactions were noted in several subtypes of BC, and were not limited to luminal-A or TNBC cells. Thus, it is highly plausible that Notch-inflammation interactions actually have a general tumor-promoting impact in $B C$, as may be the case in other malignancies as well. Therefore, Notch-inflammation networks may be considered as a therapy target shared by many cancer types. Yet, as tumors demonstrate a high level of inter-tumor and intra-tumor heterogeneity, the impacts and the specific participants of Notch-inflammation networks may depend on disease types and subtypes and may also reflect the diversity in the research systems and tools used. This variability calls upon extensive research that will identify the precise mechanisms that connect the Notch pathway and inflammatory elements in different types of cancer.

Second, in all three networks described in this review article, the Notch-inflammation interplay was reciprocal, exemplified by the ability of the Notch pathway to induce pro-inflammatory conditions and vice versa. As much as Notch family members were found to promote tumor-supporting functions of macrophages, macrophages affected pro-metastatic activities in BC cells through the Notch pathway. In similarity, Notch activation could stimulate IL-6-induced pathways, and in parallel the reciprocal direction was active, both leading to pro-tumor activities in BC. By the same token, Notch signaling pathways often promoted tumor-related functions by activating the NF- $\mathrm{kB}$ pathway, and Notch activation by the NF- $\mathrm{kB}$ pathway was also taking place in the BC setting.

These reciprocal relationships between Notch and inflammation, exerted through many different mechanisms and generally leading to pro-tumor activities in different $\mathrm{BC}$ subtypes, illustrate the strength and importance of the interactive Notch-inflammation network. Thus, these findings set the Notch pathway and inflammatory elements as therapeutic targets that should be pursued simultaneously in $\mathrm{BC}$ treatment, and possibly in other cancer types as well.

In recent years, different GSIs demonstrated encouraging anti-tumor potential in pre-clinical studies of several cancer types including of the breast (reviewed in $[8,14,127])$. Yet, many of the clinical trials that have evaluated GSIs for their efficacy as mono-therapies have led to unsatisfactory results or were terminated due to low tolerability and/or limited dose-dependent anti-tumor activity. As single treatment, GSIs may present several potential disadvantages. First, GSIs fail to distinguish between the different Notch receptors, some of which may have context- and tumor-dependent opposing roles. Furthermore, as $\gamma$-secretase cleaves additional targets, GSI treatment might result in off-target effects and unselective inhibition of other signaling pathways. Additional limitation of long-term GSI treatment is the gastrointestinal toxicity since Notch signaling is required for maintaining the normal function of the intestinal epithelium [128].

To address the specificity concerns of pan-Notch pathway blockade in the clinic, monoclonal antibodies (mAbs) were and are currently developed as a new therapeutic strategy for a specific inhibition of Notch signaling. For instance, anti-DLL4 mAbs (Demcizumab) and mAbs targeting Notch 
2/3 (Tarextumab) are being evaluated in pre-clinical and in early phase clinical settings for their safety and therapeutic effects in solid tumors including of the breast, demonstrating initial evidence for anti-tumor activity and/or disease stabilization [8,129-131]. However, similarly to GSIs, clinical use of one specific $\mathrm{mAb}$ as a single agent most likely will not eliminate the potentially harmful side-effects of Notch pathway inhibition in non-cancerous tissues; in fact, dose-limiting toxicities have been reported in phase I studies of such mAbs [129,130,132].

Data presented in this review on the central roles of each of the partners alone and more so, of combined Notch-inflammation networks, strongly suggests that in future clinical studies it would be beneficial to aim at combination therapies targeting these two axes together as a rational strategy for BC. This option is especially attractive when the toxicity of GSIs is considered, raising the possibility that in the presence of inflammation inhibitors, the doses of GSI or other Notch inhibitors (e.g., Abs) could be reduced. Indeed, some of inflammation inhibitors are already in clinical use. For example, $\mathrm{mAbs}$ against the IL-6 receptor are in clinical use for the treatment of rheumatoid arthritis [133]. TNF $\alpha$ and IL-1 $\beta$ inhibitors are in clinical use for inflammatory diseases and autoimmune disorders [134-136] and were demonstrated to inhibit the aggressiveness phenotype of BC cells (as cited above). Under conditions of simultaneous inhibition of Notch-inflammation, it is possible that more effective and safer treatment modalities could be offered to $B C$ patients and to individuals suffering from other malignancies alike.

Author Contributions: Y.L. contributed to literature search, data organization, manuscript design and writing; A.B.-B. contributed to all of these aspects and to figure preparation, and was responsible for the entire setup and structure design of the manuscript. All authors have read and agree to the published version of the manuscript.

Funding: This research received no external funding

Acknowledgments: The authors thank the granting foundations whose support along the years has contributed to studies at the Ben-Baruch laboratory, on topics relevant to this review. Specifically, the support by the Israel Science Foundation, Israel Cancer Association, Israel Cancer Research Fund and Federico Foundation is acknowledged. The authors also thank members of the Ben-Baruch group for their contribution along the years to the laboratory's research.

Conflicts of Interest: The authors declare that they do not have any non-financial competing interests and that they do not have a financial relationship with the organizations that sponsored the research or that supported participation in conferences.

\section{References}

1. Reichrath, J.; Reichrath, S. Notch Signaling and Embryonic Development: An Ancient Friend, Revisited. Adv. Exp. Med. Biol. 2020, 1218, 9-37. [CrossRef] [PubMed]

2. Vanorny, D.A.; Mayo, E.K. The role of Notch signaling in the mammalian ovary. Reproduction 2017, 153, R187-R204. [CrossRef] [PubMed]

3. Tsaouli, G.; Barbarulo, A.; Vacca, A.; Screpanti, I.; Felli, M.P. Molecular Mechanisms of Notch Signaling in Lymphoid Cell Lineages Development: NF-kB and Beyond. Adv. Exp. Med. Biol. 2020, 1227, 145-164. [CrossRef] [PubMed]

4. Kiyokawa, H.; Morimoto, M. Notch signaling in the mammalian respiratory system, specifically the trachea and lungs, in development, homeostasis, regeneration, and disease. Dev. Growth Differ. 2019, 62, 67-79. [CrossRef] [PubMed]

5. Aquila, G.; Kostina, A.; Vieceli Dalla Sega, F.; Shlyakhto, E.; Kostareva, A.; Marracino, L.; Ferrari, R.; Rizzo, P.; Malaschicheva, A. The Notch pathway: A novel therapeutic target for cardiovascular diseases? Expert Opin. Ther. Targets 2019, 23, 695-710. [CrossRef] [PubMed]

6. Ho, D.M.; Artavanis-Tsakonas, S.; Louvi, A. The Notch pathway in CNS homeostasis and neurodegeneration. Wiley Interdiscip. Rev. Dev. Biol. 2020, 9, e358. [CrossRef] [PubMed]

7. Ranganathan, P.; Weaver, K.L.; Capobianco, A.J. Notch signalling in solid tumours: A little bit of everything but not all the time. Nat. Rev. Cancer 2011, 11, 338-351. [CrossRef]

8. Takebe, N.; Nguyen, D.; Yang, S.X. Targeting notch signaling pathway in cancer: Clinical development advances and challenges. Pharmacol. Ther. 2014, 141, 140-149. [CrossRef] 
9. Li, L.; Tang, P.; Li, S.; Qin, X.; Yang, H.; Wu, C.; Liu, Y. Notch signaling pathway networks in cancer metastasis: A new target for cancer therapy. Med. Oncol. 2017, 34, 180. [CrossRef]

10. Meurette, O. Shaping of the Tumor Microenvironment by Notch Signaling. Adv. Exp. Med. Biol. 2020, 1223, 1-16.

11. Aster, J.C.; Pear, W.S.; Blacklow, S.C. The Varied Roles of Notch in Cancer. Annu. Rev. Pathol. 2017, 12, 245-275. [CrossRef] [PubMed]

12. Lamy, M.; Ferreira, A.; Dias, J.S.; Braga, S.; Silva, G.; Barbas, A. Notch-out for breast cancer therapies. New Biotechnol. 2017, 39, 215-221. [CrossRef] [PubMed]

13. Braune, E.B.; Seshire, A.; Lendahl, U. Notch and Wnt Dysregulation and Its Relevance for Breast Cancer and Tumor Initiation. Biomedicines 2018, 6, 101. [CrossRef]

14. Mollen, E.W.J.; Ient, J.; Tjan-Heijnen, V.C.G.; Boersma, L.J.; Miele, L.; Smidt, M.L.; Vooijs, M. Moving Breast Cancer Therapy up a Notch. Front. Oncol. 2018, 8, 518. [CrossRef] [PubMed]

15. Zhang, Y.; Xie, Z.Y.; Guo, X.T.; Xiao, X.H.; Xiong, L.X. Notch and breast cancer metastasis: Current knowledge, new sights and targeted therapy. Oncol. Lett. 2019, 18, 2743-2755. [CrossRef]

16. Kontomanolis, E.N.; Kalagasidou, S.; Pouliliou, S.; Anthoulaki, X.; Georgiou, N.; Papamanolis, V.; Fasoulakis, Z.N. The Notch Pathway in Breast Cancer Progression. Sci. World J. 2018, 2018, 2415489. [CrossRef]

17. Guo, S.; Liu, M.; Gonzalez-Perez, R.R. Role of Notch and its oncogenic signaling crosstalk in breast cancer. Biochim. Biophys. Acta. 2011, 1815, 197-213. [CrossRef]

18. Harbeck, N.; Penault-Llorca, F.; Cortes, J.; Gnant, M.; Houssami, N.; Poortmans, P.; Ruddy, K.; Tsang, J.; Cardoso, F. Breast cancer. Nat. Rev. Dis. Primers 2019, 5, 66. [CrossRef]

19. Eroles, P.; Bosch, A.; Perez-Fidalgo, J.A.; Lluch, A. Molecular biology in breast cancer: Intrinsic subtypes and signaling pathways. Cancer Treat. Rev. 2012, 38, 698-707. [CrossRef]

20. Gerratana, L.; Fanotto, V.; Bonotto, M.; Bolzonello, S.; Andreetta, C.; Moroso, S.; Pascoletti, G.; Fasole, G.; Puglisi, F. Pattern of metastatic spread and prognosis of breast cancer biologic subtypes. J. Clin. Oncol. 2014, 32, e12532. [CrossRef]

21. Gallahan, D.; Callahan, R. The mouse mammary tumor associated gene INT3 is a unique member of the NOTCH gene family (NOTCH4). Oncogene 1997, 14, 1883-1890. [CrossRef] [PubMed]

22. Raafat, A.; Bargo, S.; Anver, M.R.; Callahan, R. Mammary development and tumorigenesis in mice expressing a truncated human Notch4/Int3 intracellular domain (h-Int3sh). Oncogene 2004, 23, 9401-9407. [CrossRef] [PubMed]

23. Liu, Y.; Su, C.; Shan, Y.; Yang, S.; Ma, G. Targeting Notch1 inhibits invasion and angiogenesis of human breast cancer cells via inhibition Nuclear Factor-kappaB signaling. Am. J. Transl. Res. 2016, 8, 2681-2692. [PubMed]

24. Xie, X.; Kaoud, T.S.; Edupuganti, R.; Zhang, T.; Kogawa, T.; Zhao, Y.; Chauhan, G.B.; Giannoukos, D.N.; Qi, Y.; Tripathy, D.; et al. c-Jun N-terminal kinase promotes stem cell phenotype in triple-negative breast cancer through upregulation of Notch1 via activation of c-Jun. Oncogene 2017, 36, 2599-2608. [CrossRef]

25. Andrieu, G.; Tran, A.H.; Strissel, K.J.; Denis, G.V. BRD4 Regulates Breast Cancer Dissemination through Jagged1/Notch1 Signaling. Cancer Res. 2016, 76, 6555-6567. [CrossRef] [PubMed]

26. Zhou, Y.F.; Sun, Q.; Zhang, Y.J.; Wang, G.M.; He, B.; Qi, T.; Zhou, Y.; Li, X.W.; Li, S.; He, L. Targeted inhibition of Notch1 gene enhances the killing effects of paclitaxel on triple negative breast cancer cells. Asian Pac. J. Trop. Med. 2017, 10, 179-183. [CrossRef]

27. Zhang, J.; Shao, X.; Sun, H.; Liu, K.; Ding, Z.; Chen, J.; Fang, L.; Su, W.; Hong, Y.; Li, H.; et al. NUMB negatively regulates the epithelial-mesenchymal transition of triple-negative breast cancer by antagonizing Notch signaling. Oncotarget 2016, 7, 61036-61053. [CrossRef]

28. Acar, A.; Simoes, B.M.; Clarke, R.B.; Brennan, K. A Role for Notch Signalling in Breast Cancer and Endocrine Resistance. Stem Cells Int. 2016, 2016, 2498764. [CrossRef]

29. Speiser, J.; Foreman, K.; Drinka, E.; Godellas, C.; Perez, C.; Salhadar, A.; Ersahin, C.; Rajan, P. Notch-1 and Notch-4 biomarker expression in triple-negative breast cancer. Int. J. Surg. Pathol. 2012, 20, 139-145. [CrossRef]

30. Mittal, S.; Sharma, A.; Balaji, S.A.; Gowda, M.C.; Dighe, R.R.; Kumar, R.V.; Rangarajan, A. Coordinate hyperactivation of Notch1 and Ras/MAPK pathways correlates with poor patient survival: Novel therapeutic strategy for aggressive breast cancers. Mol. Cancer Ther. 2014, 13, 3198-3209. [CrossRef] 
31. Lee, C.W.; Simin, K.; Liu, Q.; Plescia, J.; Guha, M.; Khan, A.; Hsieh, C.C.; Altieri, D.C. A functional Notch-survivin gene signature in basal breast cancer. Breast Cancer Res. 2008, 10, R97. [CrossRef] [PubMed]

32. Reedijk, M.; Odorcic, S.; Chang, L.; Zhang, H.; Miller, N.; McCready, D.R.; Lockwood, G.; Egan, S.E. High-level coexpression of JAG1 and NOTCH1 is observed in human breast cancer and is associated with poor overall survival. Cancer Res. 2005, 65, 8530-8537. [CrossRef] [PubMed]

33. Yuan, X.; Zhang, M.; Wu, H.; Xu, H.; Han, N.; Chu, Q.; Yu, S.; Chen, Y.; Wu, K. Expression of Notch1 Correlates with Breast Cancer Progression and Prognosis. PLoS ONE 2015, 10, e0131689. [CrossRef] [PubMed]

34. Kumar, S.; Srivastav, R.K.; Wilkes, D.W.; Ross, T.; Kim, S.; Kowalski, J.; Chatla, S.; Zhang, Q.; Nayak, A.; Guha, M.; et al. Estrogen-dependent DLL1-mediated Notch signaling promotes luminal breast cancer. Oncogene 2019, 38, 2092-2107. [CrossRef]

35. Jia, X.; Wang, W.; Xu, Z.; Wang, S.; Wang, T.; Wang, M.; Wu, M. A humanized anti-DLL4 antibody promotes dysfunctional angiogenesis and inhibits breast tumor growth. Sci. Rep. 2016, 6, 27985. [CrossRef]

36. Lee, G.H.; Yoo, K.C.; An, Y.; Lee, H.J.; Lee, M.; Uddin, N.; Kim, M.J.; Kim, I.G.; Suh, Y.; Lee, S.J. FYN promotes mesenchymal phenotypes of basal type breast cancer cells through STAT5/NOTCH2 signaling node. Oncogene 2018, 37, 1857-1868. [CrossRef]

37. Simoes, B.M.; O’Brien, C.S.; Eyre, R.; Silva, A.; Yu, L.; Sarmiento-Castro, A.; Alferez, D.G.; Spence, K.; Santiago-Gomez, A.; Chemi, F.; et al. Anti-estrogen Resistance in Human Breast Tumors Is Driven by JAG1-NOTCH4-Dependent Cancer Stem Cell Activity. Cell Rep. 2015, 12, 1968-1977. [CrossRef]

38. Hu, C.; Dievart, A.; Lupien, M.; Calvo, E.; Tremblay, G.; Jolicoeur, P. Overexpression of activated murine Notch1 and Notch3 in transgenic mice blocks mammary gland development and induces mammary tumors. Am. J. Pathol. 2006, 168, 973-990. [CrossRef]

39. Dievart, A.; Beaulieu, N.; Jolicoeur, P. Involvement of Notch1 in the development of mouse mammary tumors. Oncogene 1999, 18, 5973-5981. [CrossRef]

40. Stoeck, A.; Lejnine, S.; Truong, A.; Pan, L.; Wang, H.; Zang, C.; Yuan, J.; Ware, C.; MacLean, J.; Garrett-Engele, P.W.; et al. Discovery of biomarkers predictive of GSI response in triple-negative breast cancer and adenoid cystic carcinoma. Cancer Discov. 2014, 4, 1154-1167. [CrossRef]

41. Robinson, D.R.; Kalyana-Sundaram, S.; Wu, Y.M.; Shankar, S.; Cao, X.; Ateeq, B.; Asangani, I.A.; Iyer, M.; Maher, C.A.; Grasso, C.S.; et al. Functionally recurrent rearrangements of the MAST kinase and Notch gene families in breast cancer. Nat. Med. 2011, 17, 1646-1651. [CrossRef] [PubMed]

42. Wang, K.; Zhang, Q.; Li, D.; Ching, K.; Zhang, C.; Zheng, X.; Ozeck, M.; Shi, S.; Li, X.; Wang, H.; et al. PEST domain mutations in Notch receptors comprise an oncogenic driver segment in triple-negative breast cancer sensitive to a gamma-secretase inhibitor. Clin. Cancer Res. 2015, 21, 1487-1496. [CrossRef] [PubMed]

43. Grivennikov, S.I.; Greten, F.R.; Karin, M. Immunity, inflammation, and cancer. Cell 2010, 140, $883-899$. [CrossRef] [PubMed]

44. Crusz, S.M.; Balkwill, F.R. Inflammation and cancer: Advances and new agents. Nat. Rev. Clin. Oncol. 2015, 12, 584-596. [CrossRef]

45. Colotta, F.; Allavena, P.; Sica, A.; Garlanda, C.; Mantovani, A. Cancer-related inflammation, the seventh hallmark of cancer: Links to genetic instability. Carcinogenesis 2009, 30, 1073-1081. [CrossRef]

46. Balkwill, F.R.; Mantovani, A. Cancer-related inflammation: Common themes and therapeutic opportunities. Semin. Cancer Biol. 2012, 22, 33-40. [CrossRef]

47. Galdiero, M.R.; Marone, G.; Mantovani, A. Cancer Inflammation and Cytokines. Cold Spring Harb. Perspect. Biol. 2018, 10, a028662. [CrossRef]

48. Jiang, X.; Shapiro, D.J. The immune system and inflammation in breast cancer. Mol. Cell Endocrinol. 2014, 382, 673-682. [CrossRef]

49. Esquivel-Velazquez, M.; Ostoa-Saloma, P.; Palacios-Arreola, M.I.; Nava-Castro, K.E.; Castro, J.I.; Morales-Montor, J. The role of cytokines in breast cancer development and progression. J. Interferon Cytokine Res. 2015, 35, 1-16. [CrossRef]

50. Goldberg, J.E.; Schwertfeger, K.L. Proinflammatory cytokines in breast cancer: Mechanisms of action and potential targets for therapeutics. Curr. Drug Targets 2010, 11, 1133-1146. [CrossRef]

51. Harris, R.E.; Casto, B.C.; Harris, Z.M. Cyclooxygenase-2 and the inflammogenesis of breast cancer. World J. Clin. Oncol. 2014, 5, 677-692. [CrossRef] [PubMed]

52. Ham, M.; Moon, A. Inflammatory and microenvironmental factors involved in breast cancer progression. Arch. Pharm. Res. 2013, 36, 1419-1431. [CrossRef] [PubMed] 
53. Acharyya, S.; Oskarsson, T.; Vanharanta, S.; Malladi, S.; Kim, J.; Morris, P.G.; Manova-Todorova, K.; Leversha, M.; Hogg, N.; Seshan, V.E.; et al. A CXCL1 paracrine network links cancer chemoresistance and metastasis. Cell 2012, 150, 165-178. [CrossRef]

54. Palacios-Arreola, M.I.; Nava-Castro, K.E.; Castro, J.I.; Garcia-Zepeda, E.; Carrero, J.C.; Morales-Montor, J. The role of chemokines in breast cancer pathology and its possible use as therapeutic targets. J. Immunol. Res. 2014, 2014, 849720. [CrossRef] [PubMed]

55. White, C.M.; Martin, B.K.; Lee, L.F.; Haskill, J.S.; Ting, J.P. Effects of paclitaxel on cytokine synthesis by unprimed human monocytes, T lymphocytes, and breast cancer cells. Cancer Immunol. Immunother. 1998, 46, 104-112. [CrossRef] [PubMed]

56. Chen, D.R.; Lu, D.Y.; Lin, H.Y.; Yeh, W.L. Mesenchymal stem cell-induced doxorubicin resistance in triple negative breast cancer. Biomed. Res. Int. 2014, 2014, 532161. [CrossRef] [PubMed]

57. Rose, D.P.; Gracheck, P.J.; Vona-Davis, L. The Interactions of Obesity, Inflammation and Insulin Resistance in Breast Cancer. Cancers 2015, 7, 2147-2168. [CrossRef]

58. Stagg, J.; Allard, B. Immunotherapeutic approaches in triple-negative breast cancer: Latest research and clinical prospects. Ther. Adv. Med. Oncol. 2013, 5, 169-181. [CrossRef]

59. Matsumoto, H.; Koo, S.L.; Dent, R.; Tan, P.H.; Iqbal, J. Role of inflammatory infiltrates in triple negative breast cancer. J. Clin. Pathol. 2015, 68, 506-510. [CrossRef]

60. Masuda, H.; Baggerly, K.A.; Wang, Y.; Iwamoto, T.; Brewer, T.; Pusztai, L.; Kai, K.; Kogawa, T.; Finetti, P.; Birnbaum, D.; et al. Comparison of molecular subtype distribution in triple-negative inflammatory and non-inflammatory breast cancers. Breast Cancer Res. 2013, 15, R112. [CrossRef]

61. Hartman, Z.C.; Poage, G.M.; den Hollander, P.; Tsimelzon, A.; Hill, J.; Panupinthu, N.; Zhang, Y.; Mazumdar, A.; Hilsenbeck, S.G.; Mills, G.B.; et al. Growth of triple-negative breast cancer cells relies upon coordinate autocrine expression of the proinflammatory cytokines IL-6 and IL-8. Cancer Res. 2013, 73, 3470-3480. [CrossRef] [PubMed]

62. Biswas, T.E.; Jimmy, T.; Walker, P.R.; James, S.E.; Prasad, S.; Zagar, T. Inflammatory TNBC breast cancer: Demography and clinical outcome in a large cohort of TNBC patients. J. Clin. Oncol. 2014, 32, e12036. [CrossRef]

63. Sica, A.; Massarotti, M. Myeloid suppressor cells in cancer and autoimmunity. J. Autoimmun. 2017, 85, 117-125. [CrossRef] [PubMed]

64. Ostrand-Rosenberg, S. Myeloid derived-suppressor cells: Their role in cancer and obesity. Curr Opin. Immunol. 2018, 51, 68-75. [CrossRef] [PubMed]

65. Bronte, V.; Brandau, S.; Chen, S.H.; Colombo, M.P.; Frey, A.B.; Greten, T.F.; Mandruzzato, S.; Murray, P.J.; Ochoa, A.; Ostrand-Rosenberg, S.; et al. Recommendations for myeloid-derived suppressor cell nomenclature and characterization standards. Nat. Commun. 2016, 7, 12150. [CrossRef] [PubMed]

66. Mishalian, I.; Granot, Z.; Fridlender, Z.G. The diversity of circulating neutrophils in cancer. Immunobiology 2017, 222, 82-88. [CrossRef]

67. Peng, D.; Tanikawa, T.; Li, W.; Zhao, L.; Vatan, L.; Szeliga, W.; Wan, S.; Wei, S.; Wang, Y.; Liu, Y.; et al. Myeloid-Derived Suppressor Cells Endow Stem-like Qualities to Breast Cancer Cells through IL6/STAT3 and NO/NOTCH Cross-talk Signaling. Cancer Res. 2016, 76, 3156-3165. [CrossRef]

68. Qiu, S.Q.; Waaijer, S.J.H.; Zwager, M.C.; de Vries, E.G.E.; van der Vegt, B.; Schroder, C.P. Tumor-associated macrophages in breast cancer: Innocent bystander or important player? Cancer Treat. Rev. 2018, 70, 178-189. [CrossRef]

69. Santoni, M.; Romagnoli, E.; Saladino, T.; Foghini, L.; Guarino, S.; Capponi, M.; Giannini, M.; Cognigni, P.D.; Ferrara, G.; Battelli, N. Triple negative breast cancer: Key role of Tumor-Associated Macrophages in regulating the activity of anti-PD-1/PD-L1 agents. Biochim. Biophys. Acta. Rev. Cancer 2018, 1869, 78-84. [CrossRef]

70. Mantovani, A.; Marchesi, F.; Malesci, A.; Laghi, L.; Allavena, P. Tumour-associated macrophages as treatment targets in oncology. Nat. Rev. Clin. Oncol. 2017, 14, 399-416. [CrossRef]

71. Poh, A.R.; Ernst, M. Targeting Macrophages in Cancer: From Bench to Bedside. Front. Oncol. 2018, 8, 49. [CrossRef] [PubMed]

72. Ruffell, B.; Affara, N.I.; Coussens, L.M. Differential macrophage programming in the tumor microenvironment. Trends. Immunol. 2012, 33, 119-126. [CrossRef] [PubMed]

73. Biswas, S.K.; Lewis, C.E. NF-kappaB as a central regulator of macrophage function in tumors. J. Leukoc. Biol. 2010, 88, 877-884. [CrossRef] [PubMed] 
74. Balkwill, F. Tumour necrosis factor and cancer. Nat. Rev. Cancer 2009, 9, 361-371. [CrossRef] [PubMed]

75. Bent, R.; Moll, L.; Grabbe, S.; Bros, M. Interleukin-1 Beta-A Friend or Foe in Malignancies? Int. J. Mol. Sci. 2018, 19, 2155. [CrossRef] [PubMed]

76. Greten, F.R.; Grivennikov, S.I. Inflammation and Cancer: Triggers, Mechanisms, and Consequences. Immunity 2019, 51, 27-41. [CrossRef] [PubMed]

77. Tulotta, C.; Ottewell, P. The role of IL-1B in breast cancer bone metastasis. Endocr. Relat. Cancer 2018, 25, R421-R434. [CrossRef]

78. Martinez-Reza, I.; Diaz, L.; Garcia-Becerra, R. Preclinical and clinical aspects of TNF-alpha and its receptors TNFR1 and TNFR2 in breast cancer. J. Biomed. Sci. 2017, 24, 90. [CrossRef]

79. Salamanna, F.; Borsari, V.; Contartese, D.; Costa, V.; Giavaresi, G.; Fini, M. What Is the Role of Interleukins in Breast Cancer Bone Metastases? A Systematic Review of Preclinical and Clinical Evidence. Cancers 2019, 11, 2018. [CrossRef]

80. Murray, P.J.; Allen, J.E.; Biswas, S.K.; Fisher, E.A.; Gilroy, D.W.; Goerdt, S.; Gordon, S.; Hamilton, J.A.; Ivashkiv, L.B.; Lawrence, T.; et al. Macrophage activation and polarization: Nomenclature and experimental guidelines. Immunity 2014, 41, 14-20. [CrossRef]

81. Cassetta, L.; Pollard, J.W. Targeting macrophages: Therapeutic approaches in cancer. Nat. Rev. Drug. Discov. 2018, 17, 887-904. [CrossRef] [PubMed]

82. Palaga, T.; Wongchana, W.; Kueanjinda, P. Notch Signaling in Macrophages in the Context of Cancer Immunity. Front. Immunol. 2018, 9, 652. [CrossRef] [PubMed]

83. Liu, H.; Wang, J.; Zhang, M.; Xuan, Q.; Wang, Z.; Lian, X.; Zhang, Q. Jagged1 promotes aromatase inhibitor resistance by modulating tumor-associated macrophage differentiation in breast cancer patients. Breast Cancer Res. Treat. 2017, 166, 95-107. [CrossRef] [PubMed]

84. Liu, H.; Wang, J.; Liu, Z.; Wang, L.; Liu, S.; Zhang, Q. Jagged1 modulated tumor-associated macrophage differentiation predicts poor prognosis in patients with invasive micropapillary carcinoma of the breast. Med. (Baltim.) 2017, 96, e6663. [CrossRef] [PubMed]

85. Lin, S.; Sun, L.; Lyu, X.; Ai, X.; Du, D.; Su, N.; Li, H.; Zhang, L.; Yu, J.; Yuan, S. Lactate-activated macrophages induced aerobic glycolysis and epithelial-mesenchymal transition in breast cancer by regulation of CCL5-CCR5 axis: A positive metabolic feedback loop. Oncotarget 2017, 8, 110426-110443. [CrossRef]

86. Franklin, R.A.; Liao, W.; Sarkar, A.; Kim, M.V.; Bivona, M.R.; Liu, K.; Pamer, E.G.; Li, M.O. The cellular and molecular origin of tumor-associated macrophages. Science 2014, 344, 921-925. [CrossRef]

87. Wang, H.; Zang, C.; Taing, L.; Arnett, K.L.; Wong, Y.J.; Pear, W.S.; Blacklow, S.C.; Liu, X.S.; Aster, J.C. NOTCH1-RBPJ complexes drive target gene expression through dynamic interactions with superenhancers. Proc. Natl. Acad. Sci. USA 2014, 111, 705-710. [CrossRef]

88. Yamamoto, M.; Taguchi, Y.; Ito-Kureha, T.; Semba, K.; Yamaguchi, N.; Inoue, J. NF-kappaB non-cell-autonomously regulates cancer stem cell populations in the basal-like breast cancer subtype. Nat. Commun. 2013, 4, 2299. [CrossRef]

89. Cabrera, R.M.; Mao, S.P.H.; Surve, C.R.; Condeelis, J.S.; Segall, J.E. A novel neuregulin-Jagged1 paracrine loop in breast cancer transendothelial migration. Breast Cancer Res. 2018, 20, 24. [CrossRef]

90. Shen, Q.; Cohen, B.; Zheng, W.; Rahbar, R.; Martin, B.; Murakami, K.; Lamorte, S.; Thompson, P.; Berman, H.; Zuniga-Pflucker, J.C.; et al. Notch Shapes the Innate Immunophenotype in Breast Cancer. Cancer Discov. 2017, 7, 1320-1335. [CrossRef]

91. Kang, S.; Tanaka, T.; Narazaki, M.; Kishimoto, T. Targeting Interleukin-6 Signaling in Clinic. Immunity 2019, 50, 1007-1023. [CrossRef] [PubMed]

92. Taher, M.Y.; Davies, D.M.; Maher, J. The role of the interleukin (IL)-6/IL-6 receptor axis in cancer. Biochem. Soc. Trans. 2018, 46, 1449-1462. [CrossRef] [PubMed]

93. Mendez-Garcia, L.A.; Nava-Castro, K.E.; Ochoa-Mercado, T.L.; Palacios-Arreola, M.I.; Ruiz-Manzano, R.A.; Segovia-Mendoza, M.; Solleiro-Villavicencio, H.; Cazarez-Martinez, C.; Morales-Montor, J. Breast Cancer Metastasis: Are Cytokines Important Players During Its Development and Progression? J. Interferon. Cytokine Res. 2019, 39, 39-55. [CrossRef] [PubMed]

94. Cheng, Y.; Ma, X.L.; Wei, Y.Q.; Wei, X.W. Potential roles and targeted therapy of the CXCLs/CXCR2 axis in cancer and inflammatory diseases. Biochim. Biophys. Acta. Rev. Cancer 2019, 1871, 289-312. [CrossRef]

95. Lim, S.Y.; Yuzhalin, A.E.; Gordon-Weeks, A.N.; Muschel, R.J. Targeting the CCL2-CCR2 signaling axis in cancer metastasis. Oncotarget 2016, 7, 28697-28710. [CrossRef] 
96. Jiao, X.; Nawab, O.; Patel, T.; Kossenkov, A.V.; Halama, N.; Jaeger, D.; Pestell, R.G. Recent Advances Targeting CCR5 for Cancer and Its Role in Immuno-Oncology. Cancer Res. 2019, 79, 4801-4807. [CrossRef]

97. Liubomirski, Y.; Lerrer, S.; Meshel, T.; Rubinstein-Achiasaf, L.; Morein, D.; Wiemann, S.; Korner, C.; Ben-Baruch, A. Tumor-Stroma-Inflammation Networks Promote Pro-metastatic Chemokines and Aggressiveness Characteristics in Triple-Negative Breast Cancer. Front. Immunol. 2019, 10, 757. [CrossRef]

98. Liubomirski, Y.; Lerrer, S.; Meshel, T.; Morein, D.; Rubinstein-Achiasaf, L.; Sprinzak, D.; Wiemann, S.; Korner, C.; Ehrlich, M.; Ben-Baruch, A. Notch-Mediated Tumor-Stroma-Inflammation Networks Promote Invasive Properties and CXCL8 Expression in Triple-Negative Breast Cancer. Front. Immunol. 2019, 10, 804. [CrossRef]

99. Tsuyada, A.; Chow, A.; Wu, J.; Somlo, G.; Chu, P.; Loera, S.; Luu, T.; Li, A.X.; Wu, X.; Ye, W.; et al. CCL2 mediates cross-talk between cancer cells and stromal fibroblasts that regulates breast cancer stem cells. Cancer Res. 2012, 72, 2768-2779. [CrossRef]

100. Xing, F.; Kobayashi, A.; Okuda, H.; Watabe, M.; Pai, S.K.; Pandey, P.R.; Hirota, S.; Wilber, A.; Mo, Y.Y.; Moore, B.E.; et al. Reactive astrocytes promote the metastatic growth of breast cancer stem-like cells by activating Notch signalling in brain. EMBO Mol. Med. 2013, 5, 384-396. [CrossRef]

101. Zhang, X.; Zhao, X.; Shao, S.; Zuo, X.; Ning, Q.; Luo, M.; Gu, S.; Zhao, X. Notch1 induces epithelial-mesenchymal transition and the cancer stem cell phenotype in breast cancer cells and STAT3 plays a key role. Int. J. Oncol. 2015, 46, 1141-1148. [CrossRef] [PubMed]

102. Yumimoto, K.; Akiyoshi, S.; Ueo, H.; Sagara, Y.; Onoyama, I.; Ueo, H.; Ohno, S.; Mori, M.; Mimori, K.; Nakayama, K.I. F-box protein FBXW7 inhibits cancer metastasis in a non-cell-autonomous manner. J. Clin. Investig. 2015, 125, 621-635. [CrossRef] [PubMed]

103. Bui, Q.T.; Im, J.H.; Jeong, S.B.; Kim, Y.M.; Lim, S.C.; Kim, B.; Kang, K.W. Essential role of Notch4/STAT3 signaling in epithelial-mesenchymal transition of tamoxifen-resistant human breast cancer. Cancer Lett. 2017, 390, 115-125. [CrossRef] [PubMed]

104. Wang, D.; Xu, J.; Liu, B.; He, X.; Zhou, L.; Hu, X.; Qiao, F.; Zhang, A.; Xu, X.; Zhang, H.; et al. IL6 blockade potentiates the anti-tumor effects of gamma-secretase inhibitors in Notch3-expressing breast cancer. Cell Death Differ. 2018, 25, 330-339. [CrossRef] [PubMed]

105. Sethi, N.; Dai, X.; Winter, C.G.; Kang, Y. Tumor-derived JAGGED1 promotes osteolytic bone metastasis of breast cancer by engaging notch signaling in bone cells. Cancer Cell 2011, 19, 192-205. [CrossRef] [PubMed]

106. Sansone, P.; Storci, G.; Tavolari, S.; Guarnieri, T.; Giovannini, C.; Taffurelli, M.; Ceccarelli, C.; Santini, D.; Paterini, P.; Marcu, K.B.; et al. IL-6 triggers malignant features in mammospheres from human ductal breast carcinoma and normal mammary gland. J. Clin. Investig. 2007, 117, 3988-4002. [CrossRef]

107. Hsu, E.C.; Kulp, S.K.; Huang, H.L.; Tu, H.J.; Salunke, S.B.; Sullivan, N.J.; Sun, D.; Wicha, M.S.; Shapiro, C.L.; Chen, C.S. Function of Integrin-Linked Kinase in Modulating the Stemness of IL-6-Abundant Breast Cancer Cells by Regulating gamma-Secretase-Mediated Notch1 Activation in Caveolae. Neoplasia 2015, 17, 497-508. [CrossRef]

108. Bocci, F.; Gearhart-Serna, L.; Boareto, M.; Ribeiro, M.; Ben-Jacob, E.; Devi, G.R.; Levine, H.; Onuchic, J.N.; Jolly, M.K. Toward understanding cancer stem cell heterogeneity in the tumor microenvironment. Proc. Natl. Acad. Sci. USA 2019, 116, 148-157. [CrossRef]

109. Kim, R.K.; Kaushik, N.; Suh, Y.; Yoo, K.C.; Cui, Y.H.; Kim, M.J.; Lee, H.J.; Kim, I.G.; Lee, S.J. Radiation driven epithelial-mesenchymal transition is mediated by Notch signaling in breast cancer. Oncotarget 2016, 7, 53430-53442. [CrossRef]

110. Studebaker, A.W.; Storci, G.; Werbeck, J.L.; Sansone, P.; Sasser, A.K.; Tavolari, S.; Huang, T.; Chan, M.W.; Marini, F.C.; Rosol, T.J.; et al. Fibroblasts isolated from common sites of breast cancer metastasis enhance cancer cell growth rates and invasiveness in an interleukin-6-dependent manner. Cancer Res. 2008, 68, 9087-9095. [CrossRef]

111. Sansone, P.; Ceccarelli, C.; Berishaj, M.; Chang, Q.; Rajasekhar, V.K.; Perna, F.; Bowman, R.L.; Vidone, M.; Daly, L.; Nnoli, J.; et al. Self-renewal of CD133(hi) cells by IL6/Notch3 signalling regulates endocrine resistance in metastatic breast cancer. Nat. Commun. 2016, 7, 10442. [CrossRef] [PubMed]

112. Cantrell, M.A.; Ebelt, N.D.; Pfefferle, A.D.; Perou, C.M.; Van Den Berg, C.L. c-Jun N-terminal kinase 2 prevents luminal cell commitment in normal mammary glands and tumors by inhibiting p53/Notch1 and breast cancer gene 1 expression. Oncotarget 2015, 6, 11863-11881. [CrossRef] [PubMed] 
113. Portanova, P.; Notaro, A.; Pellerito, O.; Sabella, S.; Giuliano, M.; Calvaruso, G. Notch inhibition restores TRAIL-mediated apoptosis via AP1-dependent upregulation of DR4 and DR5 TRAIL receptors in MDA-MB-231 breast cancer cells. Int. J. Oncol. 2013, 43, 121-130. [CrossRef] [PubMed]

114. Taniguchi, K.; Karin, M. NF-kappaB, inflammation, immunity and cancer: Coming of age. Nat. Rev. Immunol. 2018, 18, 309-324. [CrossRef]

115. Zhang, Q.; Lenardo, M.J.; Baltimore, D. 30 Years of NF-kappaB: A Blossoming of Relevance to Human Pathobiology. Cell 2017, 168, 37-57. [CrossRef]

116. Osipo, C.; Golde, T.E.; Osborne, B.A.; Miele, L.A. Off the beaten pathway: The complex cross talk between Notch and NF-kappaB. Lab. Invest. 2008, 88, 11-17. [CrossRef]

117. Saito, T.; Tanaka, S. Molecular mechanisms underlying osteoarthritis development: Notch and NF-kappaB. Arthritis Res. Ther. 2017, 19, 94. [CrossRef]

118. Ferrandino, F.; Grazioli, P.; Bellavia, D.; Campese, A.F.; Screpanti, I.; Felli, M.P. Notch and NF-kappaB: Coach and Players of Regulatory T-Cell Response in Cancer. Front. Immunol. 2018, 9, 2165. [CrossRef]

119. Tsaouli, G.; Barbarulo, A.; Vacca, A.; Screpanti, I.; Felli, M.P. Molecular mechanisms of Notch signaling in lymphoid cell lineages development: NF-KB and beyond. Springer Nat. Switz. AG 2020, 1227, 145-164.

120. Wang, W.; Nag, S.A.; Zhang, R. Targeting the NFkappaB signaling pathways for breast cancer prevention and therapy. Curr. Med. Chem. 2015, 22, 264-289. [CrossRef]

121. Vlahopoulos, S.A.; Cen, O.; Hengen, N.; Agan, J.; Moschovi, M.; Critselis, E.; Adamaki, M.; Bacopoulou, F.; Copland, J.A.; Boldogh, I.; et al. Dynamic aberrant NF-kappaB spurs tumorigenesis: A new model encompassing the microenvironment. Cytokine Growth Factor Rev. 2015, 26, 389-403. [CrossRef] [PubMed]

122. Li, L.; Zhao, F.; Lu, J.; Li, T.; Yang, H.; Wu, C.; Liu, Y. Notch-1 signaling promotes the malignant features of human breast cancer through NF-kappaB activation. PLoS ONE 2014, 9, e95912.

123. Li, L.; Zhang, J.; Xiong, N.; Li, S.; Chen, Y.; Yang, H.; Wu, C.; Zeng, H.; Liu, Y. Notch-1 signaling activates NF-kappaB in human breast carcinoma MDA-MB-231 cells via PP2A-dependent AKT pathway. Med. Oncol. 2016, 33, 33. [CrossRef] [PubMed]

124. Hossain, F.; Sorrentino, C.; Ucar, D.A.; Peng, Y.; Matossian, M.; Wyczechowska, D.; Crabtree, J.; Zabaleta, J.; Morello, S.; Del Valle, L.; et al. Notch Signaling Regulates Mitochondrial Metabolism and NF-kappaB Activity in Triple-Negative Breast Cancer Cells via IKKalpha-Dependent Non-canonical Pathways. Front. Oncol. 2018, 8, 575. [CrossRef]

125. Hao, L.; Rizzo, P.; Osipo, C.; Pannuti, A.; Wyatt, D.; Cheung, L.W.; Sonenshein, G.; Osborne, B.A.; Miele, L. Notch-1 activates estrogen receptor-alpha-dependent transcription via IKKalpha in breast cancer cells. Oncogene 2010, 29, 201-213. [CrossRef]

126. Jin, S.; Mutvei, A.P.; Chivukula, I.V.; Andersson, E.R.; Ramskold, D.; Sandberg, R.; Lee, K.L.; Kronqvist, P.; Mamaeva, V.; Ostling, P.; et al. Non-canonical Notch signaling activates IL-6/JAK/STAT signaling in breast tumor cells and is controlled by p53 and IKKalpha/IKKbeta. Oncogene 2013, 32, 4892-4902. [CrossRef]

127. Takebe, N.; Miele, L.; Harris, P.J.; Jeong, W.; Bando, H.; Kahn, M.; Yang, S.X.; Ivy, S.P. Targeting Notch, Hedgehog, and Wnt pathways in cancer stem cells: Clinical update. Nat. Rev. Clin. Oncol. 2015, 12, 445-464. [CrossRef]

128. VanDussen, K.L.; Carulli, A.J.; Keeley, T.M.; Patel, S.R.; Puthoff, B.J.; Magness, S.T.; Tran, I.T.; Maillard, I.; Siebel, C.; Kolterud, A.; et al. Notch signaling modulates proliferation and differentiation of intestinal crypt base columnar stem cells. Development 2012, 139, 488-497. [CrossRef]

129. Smith, D.C.; Eisenberg, P.D.; Manikhas, G.; Chugh, R.; Gubens, M.A.; Stagg, R.J.; Kapoun, A.M.; Xu, L.; Dupont, J.; Sikic, B. A phase I dose escalation and expansion study of the anticancer stem cell agent demcizumab (anti-DLL4) in patients with previously treated solid tumors. Clin. Cancer. Res. 2014, 20, 6295-6303. [CrossRef]

130. Smith, D.C.; Chugh, R.; Patnaik, A.; Papadopoulos, K.P.; Wang, M.; Kapoun, A.M.; Xu, L.; Dupont, J.; Stagg, R.J.; Tolcher, A. A phase 1 dose escalation and expansion study of Tarextumab (OMP-59R5) in patients with solid tumors. Invest. N. Drugs 2019, 37, 722-730. [CrossRef]

131. Kleinberg, L.; Supko, J.G.; Mikkelsen, T.; Blakeley, J.O.N.; Stevens, G.; Desideri, X.Y.; Ryu, S.; Desai, B.; Giranda, V.L.; Grossman, S.A. Phase I adult brain tumor consortium (ABTC) trial of ABT-888 (veliparib), temozolomide (TMZ), and radiotherapy (RT) for newly diagnosed glioblastoma multiforme (GBM) including pharmacokinetic (PK) data. J. Clin. Oncol. 2013, 31, 2065. 
132. Jimeno, A.; LoRusso, P.; Strother, R.; Diamond, J.; Plato, L.; Younger, A.; Messersmith, W.; Kittaneh, M.; Sawyer, D.; Adriaens, L.; et al. Phase I study of REGN421 (R)/SAR153192, a fully-human delta-like ligand 4 (Dll4) monoclonal antibody (mAb), in patients with advanced solid tumors. J. Clin. Oncol. 2013, 31, 2502. [CrossRef]

133. Ogata, A.; Kato, Y.; Higa, S.; Yoshizaki, K. IL-6 inhibitor for the treatment of rheumatoid arthritis: A comprehensive review. Mod. Rheumatol. 2019, 29, 258-267. [CrossRef] [PubMed]

134. Dinarello, C.A.; Simon, A.; van der Meer, J.W. Treating inflammation by blocking interleukin-1 in a broad spectrum of diseases. Nat. Rev. Drug Discov. 2012, 11, 633-652. [CrossRef] [PubMed]

135. Li, P.; Zheng, Y.; Chen, X. Drugs for Autoimmune Inflammatory Diseases: From Small Molecule Compounds to Anti-TNF Biologics. Front. Pharmacol. 2017, 8, 460. [CrossRef]

136. Billmeier, U.; Dieterich, W.; Neurath, M.F.; Atreya, R. Molecular mechanism of action of anti-tumor necrosis factor antibodies in inflammatory bowel diseases. World J. Gastroenterol. 2016, 22, 9300-9313. [CrossRef]

(C) 2020 by the authors. Licensee MDPI, Basel, Switzerland. This article is an open access article distributed under the terms and conditions of the Creative Commons Attribution (CC BY) license (http://creativecommons.org/licenses/by/4.0/). 